\title{
Thermo-barometric constraints on the Mt. Etna 2015 eruptive event
}

\author{
P. P. Giacomoni ${ }^{1} \cdot$ F. Casetta ${ }^{1} \cdot$ V. Valenti ${ }^{2} \cdot$ C. Ferlito ${ }^{2} \cdot$ G. Lanzafame ${ }^{2} \cdot$ M. Nazzari ${ }^{3} \cdot$ M. Coltorti ${ }^{1,4}$
}

Received: 18 November 2020 / Accepted: 28 September 2021 / Published online: 9 October 2021

(c) The Author(s) 2021

\begin{abstract}
The petrological study of volcanic products emitted during the paroxysmal events of December 2015 from the summit craters of Mount Etna allow us to constrain T-P- $\mathrm{XH}_{2} \mathrm{O}$ phase stability, crystallization conditions, and mixing processes along the main open-conduit feeding system. In this study, we discuss new geochemical, thermo-barometric data and related RhyoliteMELTS modelling of the eruptive activity that involved the concomitant activation of all summit craters. The results, in comparison with the previous paroxysmal events of the 2011-2012, reinforce the model of a vertically extended feeding system and highlight that the activity at the New South-East Crater was fed by magma residing at a significantly shallower depth with respect to the Central Craters (CC) and North-East Crater (NEC), even if all conduits were fed by a common deep $(P=530-440 \mathrm{MPa})$ basic magmatic input. Plagioclase dissolution, resorption textures, and the Rhyolite-MELTS stability model corroborate its dependence on $\mathrm{H}_{2} \mathrm{O}$ content; thus, suggesting that further studies on the effect that flushing from fluids with different $\mathrm{H}_{2} \mathrm{O} / \mathrm{CO}_{2}$ ratio are needed to understand the eruption-triggering mechanisms for high energetic strombolian paroxysmal episodes.
\end{abstract}

Keywords Open conduit volcanic feeding system · Olivine and clinopyroxene thermo-barometry $\cdot$ Chemical-physical crystallisation conditions $\cdot$ Chemical and textural zoning of phenocrysts $\cdot$ Rhyolite-MELTS modeling

\section{Introduction}

Mt. Etna's persistent activity represents an almost unique opportunity to investigate the magmatic processes occurring prior and during the eruption of a complex stratovolcano, characterized by a multifaceted feeding system. Decades of petrological, geochemical, geophysical and tectonic studies on Mt. Etna have contributed to the characterization and quantification of the tectono-magmatic processes from the mantle source to eruptive activity.

\section{P. P. Giacomoni}

gcmppl@unife.it

1 Department of Physics and Earth Sciences, University of Ferrara, Ferrara, Italy

2 Department of Biological, Environmental and Geological Sciences, University of Catania, Catania, Italy

3 National Institute of Geophysics and Volcanology, Section of Rome (INGV), High Pressure and High Temperature Laboratory, Rome, Italy

4 National Institute of Geophysics and Volcanology, Section of Palermo (INGV), Palermo, Italy
The current Mt. Etna plumbing structure consists of three main feeding systems, resulting from the transtensional tectonic regional setting: (1) the central open-conduits (Corsaro and Pompilio 2004, 2009a; b; Giacomoni et al. 2018); (2) the lateral rift-related, namely the S Rift, the NE Rift and the W-Rift (Ferlito et al. 2009; Giacomoni et al. 2012), and (3) the eccentric (Rittmann 1965; Kieffer 1975; Armienti et al. 1988).

The central conduits culminate with five summit craters: Central Craters (CC) consisting of Bocca Nuova (BN) and Voragine (VOR); North-East Crater (NEC), South-East Crater (SEC) and New South-East Crater (NSEC). The height of the magma column inside the central conduits changes constantly across the $\mathrm{H}_{2} \mathrm{O}$ saturation depth, resulting in an efficient degassing of the magma, promoting the crystallization and fractionation of abundant plagioclase (Mollo et al. 2015; Giacomoni et al. 2014, 2018). Volcanic products commonly erupted at summit craters are thus highly porphyritic with a microcrystalline matrix, sometimes mingled with glassy, almost aphyric melts indicating episodes of basic magmatic inputs from the deeper portion of the plumbing system.

The activity of lateral rift-related systems is more discontinuous and strictly linked to the regional transtensive 
regime that affects the eastern flank of the volcanic edifice (Monaco et al. 1997, 2005). The 2001 and 2002-2003 lateral eruptions attracted the attention of the scientific community, highlighting that, during an eruptive event, magma can migrate from central conduits towards the rift system (Andronico et al. 2005) or alternatively intrude independently into the lateral rift systems, eventually being stored in shallow, short-lived magmatic batches (Ferlito et al. 2009; Giacomoni et al. 2012, 2014). Mixing episodes between magma batches stored along the rift structures with incoming deeper basic melts can eventually trigger highly energetic eruptions (Viccaro et al. 2006).

The eccentric system is composed of several disperse monogenetic scoria cones and associated lava flows which are apparently not connected with the central or lateral feeding systems. A petrological study on the most recent eccentric event, the 1974 eruption of Mt. De Fiore (Corsaro et al. 2009b), highlighted that eccentric eruptions can be defined as "deep-dyke fed" (DDF), differing from central and lateral eruptions which are instead fed by magma residing at shallower depths and drained from the central conduits; thus, defined as "central conduit fed" (CCF). This feature, together with notably more rapid ascent rates, constrain the physical crystallization of magma, significantly reducing the stability field of plagioclase and resulting in the emission of mostly olivine-phyric products with scarce clinopyroxene (Metrich and Rutherford 1998).

Recent geophysical, geochemical, and petrological studies (Di Grazia et al. 2006; Andronico et al. 2008; Aloisi et al. 2009; Ferlito et al. 2009; Corsaro et al. 2009a; Mollo et al. 2015; Patanè et al. 2006, 2013; Kahl et al. 2011,2013) of eruptive events occurring from 2001 to 2014 agree that the geometry of feeding conduits and changes in the physical-chemical $\left(\mathrm{P}-\mathrm{T}-f \mathrm{O}_{2}-\mathrm{XH}_{2} \mathrm{O}-\mathrm{XCO}_{2}\right)$ should be considered as the main factors governing the eruptive style rather than the magmas, which are characterized by fairly homogeneous chemical compositions.

Following the 2001 and 2002-2003 lateral events, eruptive activity since 2006 has been restricted to the five summit craters. The Voragine (VOR) is the oldest among the summit craters and has been represented in historical iconography since the fourteenth century (Cannata et al. 2018), while the cone shaped morphology of the South-East Crater (SEC) and Bocca Nuova (BN) formed in 1971 and 1969, respectively. The New South-East Crater (NSEC) is the youngest, having formed in 2006 from explosive activity originating in a pit crater, in turn created by flank collapse of the SEC in 2006 (Neri 2010; Ferlito et al. 2010).

Since magma can reside in central conduits long enough to extensively degas, most eruptions from the central craters or along fissures, which drain central conduits, are commonly effusive with weak explosive (i.e. Strombolian) activity. This type of activity, accompanied by sporadic lava fountaining, characterized the 2004-2010 period. The 2011-2013 eruptive period (Mollo et al. 2017; Giacomoni et al. 2018) represented an interesting and dramatic shift in eruptive style, whereby activity became significantly more energetic and was characterized by brief (few hours to days), strong Strombolian activity with episodes of intense lava fountaining from the NSEC, during which any remarkable seismicity was absent, defined as "paroxysmal episodes" (Behncke et al. 2014; De Beni et al. 2005).

Within this context of frequent and intense eruptive events from the NSEC, from 3 to 8 December 2015, volcanic activity affected all summit craters concomitantly: Central Craters (CC), North-East Crater (NEC) and New South-East crater (NSEC). This unusual event represented a drastic change from previous activity restricted to the NSEC, thus the December 2015 eruptive sequence provides an almost unique opportunity to study the intensive parameters affecting magmatic crystallization in the shallowest portion of the plumbing of Mt. Etna's central conduit system and relationships with the summit craters.

This study focuses on selected scoria samples from the explosive activity in December 2015; a detailed petrological, textural, thermo-barometric, hygrometric characterization was carried out to highlight any differences in the crystallization conditions of the magmas erupted from the summit craters. Results are then discussed in a comprehensive model, including data from the 2011-2012 paroxysmal events.

\section{Geological and volcanological background}

Mt Etna is a $3340 \mathrm{~m}$ a.s.l. stratovolcano located on the Ionic coast of Eastern Sicily. The volcanic edifice has been built up on the thrust between the Appennine-Maghrebian chain and the undeformed Hyblean foreland (Lentini et al. 2006). The NNW-SSE transtensive tectonic structure of the Malta Escarpment separates the thick continental lithosphere of Eastern Sicily from the thinned Ionian oceanic crust, which represents the remainder of the Jurassic Tethys ocean (Hirn et al. 1997; Micallef et al. 2018). The entire volcanic edifice is crossed by normal faults striking NNW-SSE and NNESSW, with the four summit Central Craters currently located at their intersection. On the volcano's flanks, the surface expressions of these tectonic structures are the N-S Rift and the NE Rift systems (Kieffer 1975; Monaco et al. 1997).

Magmatic activity started $\sim 500 \mathrm{ka}$ ago with the emission of olivine tholeiitic basalts, accompanied by occasional pigeonite-bearing tholeiitic basalts from fissural submarine and subaerial vents (Gillot et al. 1994; Tanguy et al. 1997). The early submarine volcanic events were followed by subaerial eruptions, together with regional uplift that occurred 300 ka ago (Branca and Del Carlo 2004). The 
composition of the erupted products shifted from tholeiitic to transitional to Na-alkaline ( $200 \mathrm{ka}$; Tanguy et al. 1997; Casetta et al. 2019). The building of the central-conduit edifice started $\sim 130 \mathrm{ka}$ ago, resulting in a sequence of several distinct volcanic centers characterized by the alternation of effusive and explosive eruptions frequently associated with caldera collapses (De Beni et al. 2005). The "Recent Mongibello" activity began $\sim 15 \mathrm{ka}$ ago, being predominantly effusive with lava emissions and Strombolian eruptions from the summit craters and/or from eccentric parasitic cones forming on the volcano's flanks (Branca and Del Carlo 2004).

\section{The December 2015 eruptive activity}

The temporal reconstruction of the eruptive event occurring between 3 and 8 December was possible thanks to the continuous monitoring and routine volcanological reports from the Istituto Nazionale di Geofisica e VulcanologiaOsservatorio Etneo (INGV-OE).

On 3 December (h 2:32-3:08 UTC), mild Strombolian activity began in the Voragine central crater (VOR) but rapidly increased to a violent yet brief lava fountain reaching over $1000 \mathrm{~m}$ in height, in turn generating a sustained eruptive column up to $12 \mathrm{~km}$ with ash fallout dispersed $30 \mathrm{~km}$ southwest from the crater (Corsaro et al. 2017). Most of the activity remained limited to the Central Crater rim, enabling the onset of lava flows. This powerful paroxysmal event lasted only a few hours, but weak ash emissions from the VOR and NSEC continued for the entire day of 3 December.

On 4 December, explosive activity resumed with two short-lasting but intense lava fountaining events from the VOR crater at 9:07-10:06 UTC and at 20.35-21:14 UTC, respectively.

Both events started with mild Strombolian activity, which rapidly shifted to strong fountaining accompanied by an eruptive column $11 \pm 2 \mathrm{~km}$ in height. Abundant ash emissions were observed at the NSEC, simultaneous with the 20:35 VOR event.

On 5 December (14.46-15.35 UTC), the intensity and frequency of explosive activity at the VOR increased and resulted in a fourth paroxysmal episode of lava fountaining.

On 6 December, the eruptive activity shifted from the VOR to the NSEC where ash emissions accompanied a scoriaceous lava flow directed towards the Valle Del Bove; at the same time, weak ash emissions were observed at the NEC crater. Later during the day, the explosive activity became strictly Strombolian while effusive activity continued to be fed by three distinct vents, flowing eastward and south-eastward into the Valle del Bove depression and reaching Mt. Centenari (Corsaro et al. 2017).

The activity at the NSEC ended on 8 December concomitantly with the onset of weak Strombolian activity at the
NEC, which lasted for the next $48 \mathrm{~h}$ and gradually decreased and ceased on 11 December.

\section{Sampling and analytical techniques}

Six rock samples were collected from the explosive activity of the Voragine Central Crater (CC) of 5 December, and from the New South-East Crater (NSEC) and North-East Crater (NEC) emitted on 6 December.

Whole-rock geochemical analyses were carried out at the laboratory of the Department of Physics and Earth Sciences, University of Ferrara (Italy) using powdered aliquots of lava and tephra. Major and some trace element $(\mathrm{Ba}, \mathrm{Cr}$, $\mathrm{Sc}, \mathrm{V}$ ) concentrations were measured by $\mathrm{X}$-ray fluorescence (Thermo ARL Advant XP) and corrected for matrix effects using the method of Lachance and Traill (1966). Loss on ignition (LOI) was determined by gravimetric method, assuming $\mathrm{Fe}_{2} \mathrm{O}_{3}$ as $15 \% \mathrm{FeO}$. $\mathrm{Zr}, \mathrm{Rb}, \mathrm{Nd}, \mathrm{Ce}, \mathrm{Nb}, \mathrm{Th}, \mathrm{U}$, and REE concentrations measured by inductively coupled plasma mass spectrometry (ICP-MS) on a VG Elemental Plasma Quad 2Plus instrument.

The data reproducibility ranges between 0.9 and $7.9 \%$; from a conservative point of view, an accuracy of $10 \%$ has been determined and a detection limit of $10 \mathrm{ppb}$ for Th, $\mathrm{U}$ and REE.

Microchemical analyses and textural images were collected at the HP-HT Laboratory of Experimental Volcanology and Geophysics of the Istituto Nazionale di Geofisica e Vulcanologia (INGV) in Rome (Italy) by means of a JEOLJXA8200 electron probe microanalyzer (EPMA) equipped with five spectrometers. Data were collected on core to rim profiles of phenocrysts, and coexisting glasses located a few microns next to crystal edges. Analytical conditions were set at an accelerating voltage of $15 \mathrm{kV}$ and a beam current of $10 \mathrm{nA}$. Phenocrysts were analyzed with a beam size of $1 \mu \mathrm{m}$ with a counting time of 20 and $10 \mathrm{~s}$ on peaks and background, respectively. For glasses, a slightly defocused electron beam with a size of $3 \mu \mathrm{m}$ was used with a counting time of $5 \mathrm{~s}$ on background and $15 \mathrm{~s}$ on the peak. The following standards have been adopted for the various chemical elements: jadeite ( $\mathrm{Si}$ and $\mathrm{Na})$, corundum $(\mathrm{Al})$, forsterite $(\mathrm{Mg})$, andradite $(\mathrm{Fe})$, rutile $(\mathrm{Ti})$, orthoclase $(\mathrm{K})$, barite $(\mathrm{Ba})$, apatite $(\mathrm{P})$, spessartine $(\mathrm{Mn})$ and chromite $(\mathrm{Cr})$. Sodium and potassium were analyzed first to mitigate alkali migration effects. The precision of the microprobe was measured through the analysis of well-characterized synthetic oxides and minerals. Data quality was ensured by analyzing the test materials as unknowns according to Iezzi et al. (2014). Based on counting statistics, analytical uncertainties relative to their reported concentrations indicate that the accuracy was better than 5\%. Images were collected using the backscattered electron (BSE) mode of a field emission gun-scanning 
electron microscope (FE-SEM) JEOL 6500F equipped with an energy dispersive spectrometer (EDS) detector.

\section{Petrography and mineral chemistry}

Petrographic features summarized in Table 1 show that all samples have a porphyritic index (PI), defined as the percentage of phenocrysts respect to the whole thin section area, ranging from $15 \%$ at NEC to $40 \%$ NSEC. Despite samples showing similar mineral paragenesis consisting of olivine ( $\mathrm{Ol})$, clinopyroxene ( $\mathrm{Cpx})$, plagioclase $(\mathrm{Plg})$ and $\mathrm{Ti}-$ magnetite (Ti-Mt), the relative percentage of phenocrysts and vesicles varies significantly.

Ol content ranges between 10 and to $20 \%$ in samples from NSEC and $20 \%$ in CC and NEC. Cpx content ranges constantly between 20 and $35 \%$ in NSEC and from 30 to $50 \%$ in $\mathrm{CC}$ and NEC; Plg content varies between 25 and $35 \%$ in $\mathrm{CC}$, up to $55 \%$ in NEC and varies from 50 to $55 \%$ in NSEC. Ti-Magnetite phenocrysts occur predominantly in the groundmass or enclosed in $\mathrm{Ol}$ and $\mathrm{Cpx}$; its content is almost constant between samples $(\sim 5 \%)$. Glomerophyric assemblages of $\mathrm{Ol}(5 \%), \mathrm{Cpx}(75-90 \%)$ and $\mathrm{Plg}(5-15 \%)$ are common in all studied samples.

Olivine phenocrysts are usually euhedral, but few larger crystals $(>4-5 \mathrm{~mm}$ ) with dissolved irregular rims are present in all samples (Fig. 1a-c). Compositions range from $\mathrm{Fo}_{56.3}$ to $\mathrm{Fo}_{82.4}$ in NSEC, from $\mathrm{Fo}_{71.7}$ to $\mathrm{Fo}_{78.9}$ in NEC and from $\mathrm{Fo}_{70.0}$ to $\mathrm{Fo}_{81.6}$ in $\mathrm{CC}$ samples.

Clinopyroxene is mostly euhedral in shape and ranges in size from $50 \mu \mathrm{m}$ to $4 \mathrm{~mm}$ (Fig. 1d-f); all analysed Cpx are diopsidic augites in composition (Morimoto 1988) with $\mathrm{Mg \#}$ content varying from 79.1 to 67.7 in NSEC, 77.8-71.7 in NEC and 81.5-69.7 in CC samples. Most Cpx phenocrysts show direct oscillatory zoning characterized by repeated micrometric dissolution surfaces. Reverse zoned Cpx, characterized by a dissolved core (74-75 Mg\#) enveloped by 76-78 Mg\# rim occur in both NEC and CC samples (Fig. 1).
Table 1 Petrographic feature of studied samples emitted during the December 2015 activity: relative proportions of phenocrysts $(\%)$, porphyritic index $(\%)$, percentage of vescicles $(\%)$ and type of groundmass

\begin{tabular}{llllllll}
\hline Sample & $\begin{array}{l}\text { Porphyritic } \\
\text { index (PI) }\end{array}$ & $\begin{array}{l}\text { Percentage of } \\
\text { vescicles }\end{array}$ & \multicolumn{3}{l}{ Relative percentage of phenocrysts } & Type of matrix \\
\cline { 4 - 6 } & & Ol & Cpx & Plg & Mt & \\
\hline CC_1 & $15 \%$ & $10 \%$ & $20 \%$ & $50 \%$ & $25 \%$ & $5 \%$ & Hyalopilitic \\
CC-2 & $20 \%$ & $15 \%$ & $20 \%$ & $40 \%$ & $35 \%$ & $5 \%$ & Hyalopilitic \\
NEC & $15 \%$ & $8 \%$ & $20 \%$ & $30 \%$ & $45 \%$ & $5 \%$ & Glassy \\
NSEC_1 & $25 \%$ & $23 \%$ & $20 \%$ & $20 \%$ & $55 \%$ & $5 \%$ & Hyalopilitic \\
NSEC_2 & $40 \%$ & $20 \%$ & $10 \%$ & $35 \%$ & $50 \%$ & $5 \%$ & Hyalopilitic \\
NSEC_3 & $25 \%$ & $25 \%$ & $20 \%$ & $20 \%$ & $55 \%$ & $5 \%$ & Hyalopilitic \\
\hline
\end{tabular}

Fig. 1 Back scattered (SEM) microphotographs of olivine $(\mathbf{a}-\mathbf{c})$, clinopyroxene $(\mathbf{d}-\mathbf{f})$ and plagioclase $(\mathbf{g}-\mathbf{i})$ in samples from Central Craters (CC), New South-East Crater (NSEC) and North-East Crater (NEC)
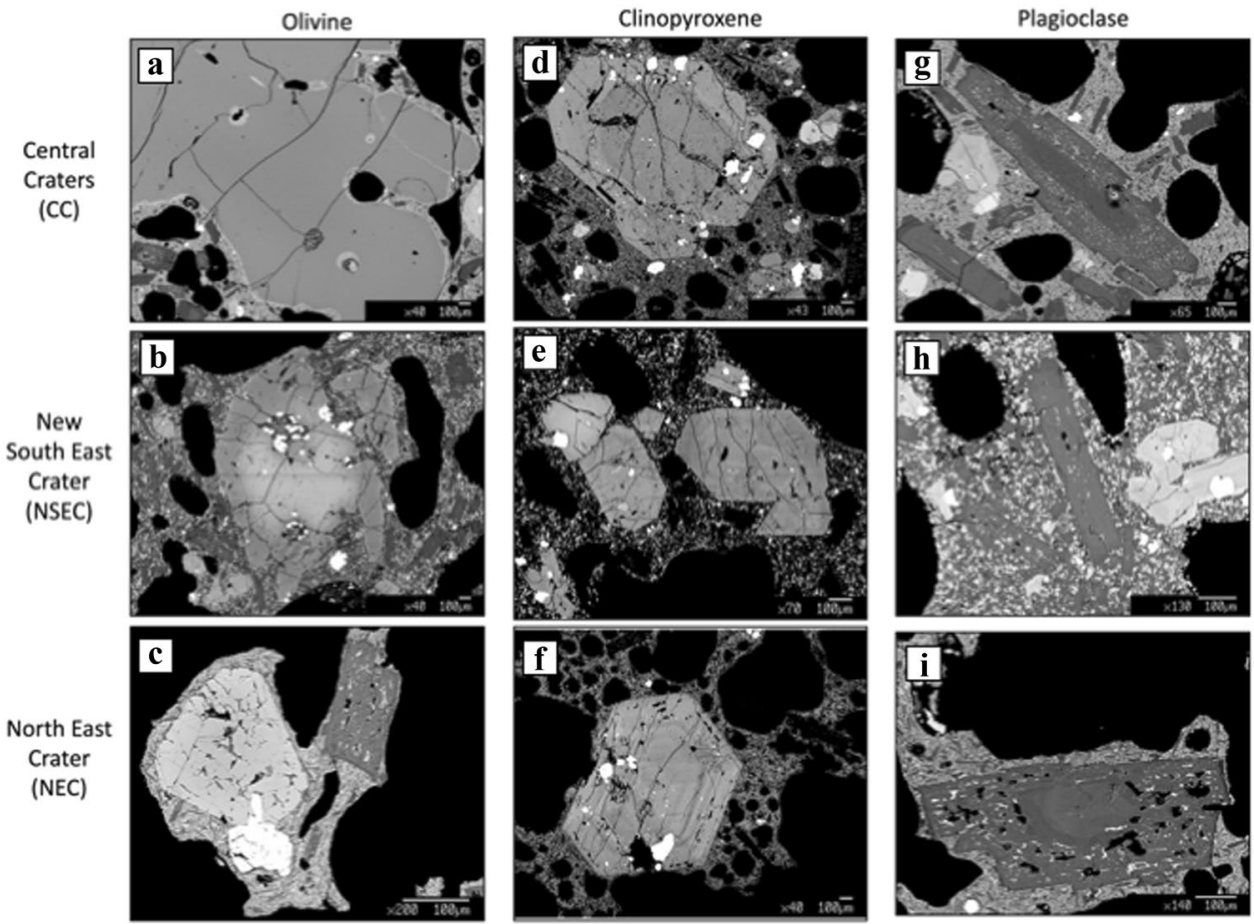
Plagioclase phenocrysts occur in two well-distinguished dimension populations. Large phenocrysts, often zoned and heavily texturized (Fig. $1 \mathrm{~g}-\mathrm{i}$ ), can reach up to $3 \mathrm{~mm}$ in size along the $\mathrm{C}$-axis. On the contrary, groundmass phenocrysts $(20-30 \mu \mathrm{m})$ are usually euhedral and homogenous in composition. Larger phenocrysts present complex dissolutionregrowth textures at cores or at rim (Fig. 2) always associated with significant compositional changes in anorthite (An) content.

Following the classification of textures proposed by Giacomoni et al. (2014); three main textures have been recognized in studied samples: i) oscillatory zoned; ii) dissolved core; iii) resorbed dusty rim.
Oscillatory zoned plagioclases are rare in large phenocrysts. They are mainly found in NSEC samples and are characterized by a low frequency oscillation in An content varying from 70 to $82 \%$ (Fig. 2e, f). Plagioclase with rounded dissolved cores (Fig. 2b, c) usually show a high An content (An88-An70) enveloped by a oscillatory An5060 regrowth. However, plagioclase with dusty resorbed rims (Fig. 2a, d) are commonly characterized by a low An oscillatory core (An60-70) enveloped by an An70-85 overgrowth made of recrystallized glass pockets and glassy channels. All three textural types are characterized by an outermost thin (up to $50 \mu \mathrm{m}$ ) overgrowth with An60-50 composition.

Opaque phenocrysts have Ti-magnetitic composition (Usp14-47 for CC, Usp29-42 for NSEC and Usp28-46 for NEC).
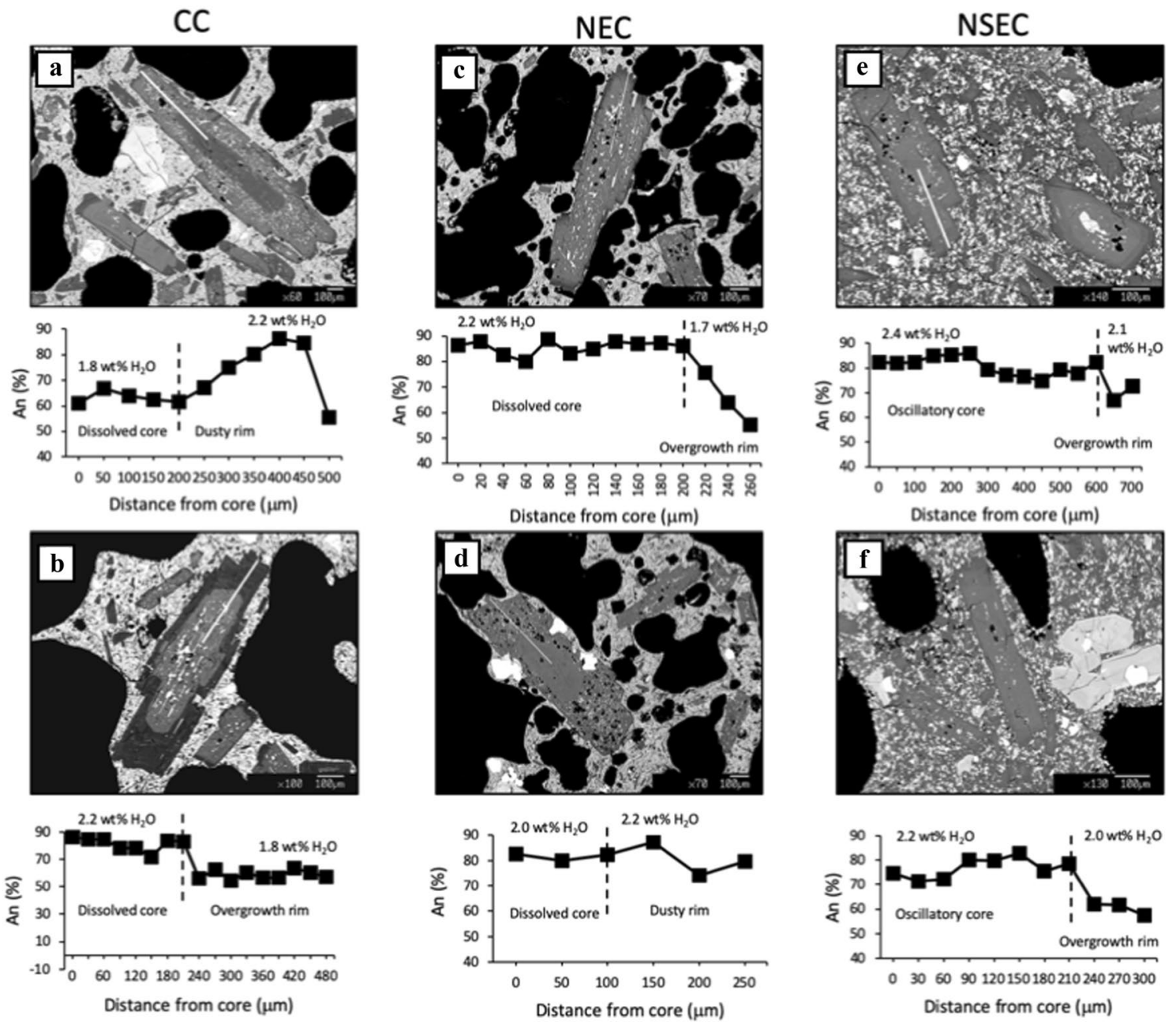

Fig. 2 Back scattered (SEM) microphotographs and anorthite content core-rim electron microprobe (EMP) profiles of studied plagioclases from Central Craters (CC; a, b); North-East Crater (NEC, c, d) and New South-East Crater (NSEC, e, f). The determined dissolved $\mathrm{H}_{2} \mathrm{O}$ content in the equilibrium melt has been obtained by means of the
Waters and Lange (2015) hygrometer. a dusty rim plagioclase associated with a $\mathrm{An}$ and $\mathrm{H}_{2} \mathrm{O}$ increase; b Rounded dissolved core followed by a An and $\mathrm{H}_{2} \mathrm{O}$ decrease; c oscillatory zoned plagioclase; d dusty rim with a An and $\mathrm{H}_{2} \mathrm{O}$ increase; e and f oscillatory zoned plagioclases from NSEC 


\section{Whole-rock geochemistry}

Whole-rock major and trace element compositions of the studied samples are summarized in Table 2. All samples are alkaline basalts (Fig. 3, Le Maitre 2002) with potassic affinity (trachybasalts). Their $\mathrm{SiO}_{2}$ content varies from 47.77 to $49.66 \mathrm{wt} \%$, at $\mathrm{Mg} \#$ (calculated as $\mathrm{MgO} /$ $[\mathrm{MgO}+\mathrm{FeO}] \mathrm{mol} \times 100$, with $\mathrm{Fe}_{2} \mathrm{O}_{3} / \mathrm{FeO}$ ratio of 0.15 ) values ranging from 45.69 to 50.56 , confirming that they lie in a restricted differentiation range, and do not significant differ from other recently erupted products from the summit Craters (Giacomoni et al. 2018). Harker's diagrams of $\mathrm{SiO}_{2}$ versus $\mathrm{CaO}, \mathrm{TiO}_{2}, \mathrm{FeO}$ and $\mathrm{CaO} / \mathrm{Al}_{2} \mathrm{O}_{3}$
Table 2 Whole-rock major (wt\%) and trace element (ppm) analyses of studied samples emitted during the December 2015 activity

\begin{tabular}{|c|c|c|c|c|c|c|}
\hline Sample & $\mathrm{CC} 1$ & $\mathrm{CC} 2$ & NEC & NSEC1 & NSEC2 & NSEC3 \\
\hline $\mathrm{SiO}_{2}$ & 50.10 & 49.14 & 48.67 & 48.26 & 48.52 & 48.59 \\
\hline $\mathrm{TiO}_{2}$ & 1.58 & 1.72 & 1.78 & 1.66 & 1.65 & 1.63 \\
\hline $\mathrm{Al}_{2} \mathrm{O}_{3}$ & 18.13 & 17.32 & 17.15 & 17.25 & 17.85 & 17.85 \\
\hline $\mathrm{FeO}$ & 7.95 & 8.82 & 9.36 & 9.31 & 9.06 & 8.89 \\
\hline $\mathrm{Fe}_{2} \mathrm{O}_{3}$ & 1.19 & 1.32 & 1.40 & 1.40 & 1.36 & 1.33 \\
\hline $\mathrm{MnO}$ & 0.18 & 0.18 & 0.19 & 0.17 & 0.18 & 0.17 \\
\hline $\mathrm{MgO}$ & 4.04 & 5.06 & 5.05 & 4.75 & 4.44 & 4.19 \\
\hline $\mathrm{CaO}$ & 9.95 & 10.17 & 10.28 & 11.11 & 10.90 & 10.90 \\
\hline $\mathrm{Na}_{2} \mathrm{O}$ & 4.32 & 3.75 & 3.68 & 4.05 & 3.94 & 4.31 \\
\hline $\mathrm{K}_{2} \mathrm{O}$ & 2.34 & 2.05 & 2.07 & 2.03 & 2.06 & 2.08 \\
\hline $\mathrm{P}_{2} \mathrm{O}_{5}$ & 0.21 & 0.46 & 0.37 & 0.00 & 0.06 & 0.03 \\
\hline LOI & 0.13 & 0.32 & 0.25 & 0.12 & 0.18 & 0.13 \\
\hline Total & 100 & 100 & 100 & 100 & 100 & 100 \\
\hline Mg\# & 47.50 & 50.56 & 49.04 & 47.64 & 46.61 & 45.69 \\
\hline $\mathrm{FeOt}$ & 9.03 & 10.02 & 10.62 & 10.56 & 10.28 & 10.09 \\
\hline Rb (ICP-MS) & 51.1 & 46.6 & 47.7 & 44.3 & 46.5 & 45.6 \\
\hline V (XRF) & 263 & 276 & 300 & 314 & 299 & 303 \\
\hline Sc (XRF) & 21.7 & 22.4 & 27.5 & 27.5 & 25.5 & 24.8 \\
\hline $\mathrm{Cr}(\mathrm{XRF})$ & 29.9 & 34.4 & 27.1 & 46.5 & 38.8 & 40.7 \\
\hline $\mathrm{Sr}$ (ICP-MS) & 956 & 831 & 988 & 994 & 1003 & 979 \\
\hline Th (XRF) & 12.6 & 10.2 & 13.5 & 9.2 & 12.4 & 12.3 \\
\hline U (ICP-MS) & 2.45 & 2.18 & 2.10 & 1.90 & 2.00 & 1.96 \\
\hline Nb (ICP-MS) & 72.5 & 64.4 & 64.1 & 56.2 & 59.5 & 59.6 \\
\hline Ba (ICP-MS) & 718 & 644 & 651 & 623 & 645 & 659 \\
\hline Ta (ICP-MS) & 2.34 & 2.09 & 2.10 & 1.91 & 2.01 & 1.99 \\
\hline La (ICP-MS) & 42.6 & 39.5 & 42.8 & 43.3 & 45.4 & 42.7 \\
\hline Ce (ICP-MS) & 101 & 92.1 & 99.3 & 91.8 & 93.7 & 92.5 \\
\hline Nd (ICP-MS) & 35.5 & 33.1 & 37.0 & 38.1 & 39.5 & 37.3 \\
\hline Pr (ICP-MS) & 8.72 & 8.17 & 9.01 & 9.18 & 9.49 & 8.99 \\
\hline Sm (ICP-MS) & 6.04 & 5.58 & 6.32 & 6.74 & 7.01 & 6.54 \\
\hline $\mathrm{Zr}$ (ICP-MS) & 285 & 248 & 242 & 234 & 254 & 252 \\
\hline Hf (ICP-MS) & 5.57 & 4.95 & 4.89 & 4.87 & 5.24 & 5.19 \\
\hline Eu (ICP-MS) & 1.74 & 1.59 & 1.84 & 1.98 & 2.07 & 1.92 \\
\hline Gd (ICP-MS) & 5.83 & 5.34 & 6.07 & 6.36 & 6.59 & 6.15 \\
\hline Dy (ICP-MS) & 3.27 & 2.93 & 3.40 & 3.78 & 4.00 & 3.69 \\
\hline Ho (ICP-MS) & 0.62 & 0.55 & 0.63 & 0.70 & 0.76 & 0.69 \\
\hline Y (ICP-MS) & 17.3 & 14.3 & 16.7 & 19.4 & 22.0 & 19.9 \\
\hline Er (ICP-MS) & 1.60 & 1.41 & 1.65 & 1.82 & 1.96 & 1.79 \\
\hline Yb (ICP-MS) & 1.33 & 1.14 & 1.35 & 1.49 & 1.62 & 1.46 \\
\hline Lu (ICP-MS) & 0.19 & 0.16 & 0.19 & 0.21 & 0.23 & 0.21 \\
\hline
\end{tabular}

Loss in ignition (LOI) was determined by gravimetric methods assuming $\mathrm{Fe}_{2} \mathrm{O}_{3}=0.15 \mathrm{FeO} . \mathrm{Mg} \#=\mathrm{Mg} /$ $(\mathrm{Mg}+\mathrm{Fe}) \mathrm{mol} \%$ 
Fig. 3 Whole-rock major elements geochemistry of studied products from the 2015 eruptive events compared with lava of 2011-2012 (red circles; Giacomoni et al. 2018). a Total alkalisilica classification diagram (Le Maitre 2002); $\mathrm{SiO}_{2}$ versus $\mathrm{CaO}(\mathbf{b}) ; \mathrm{TiO}_{2}(\mathbf{c}) ; \mathrm{FeOt}(\mathbf{d})$ and $\mathrm{CaO} / \mathrm{Al}_{2} \mathrm{O}_{3}(\mathbf{e})$

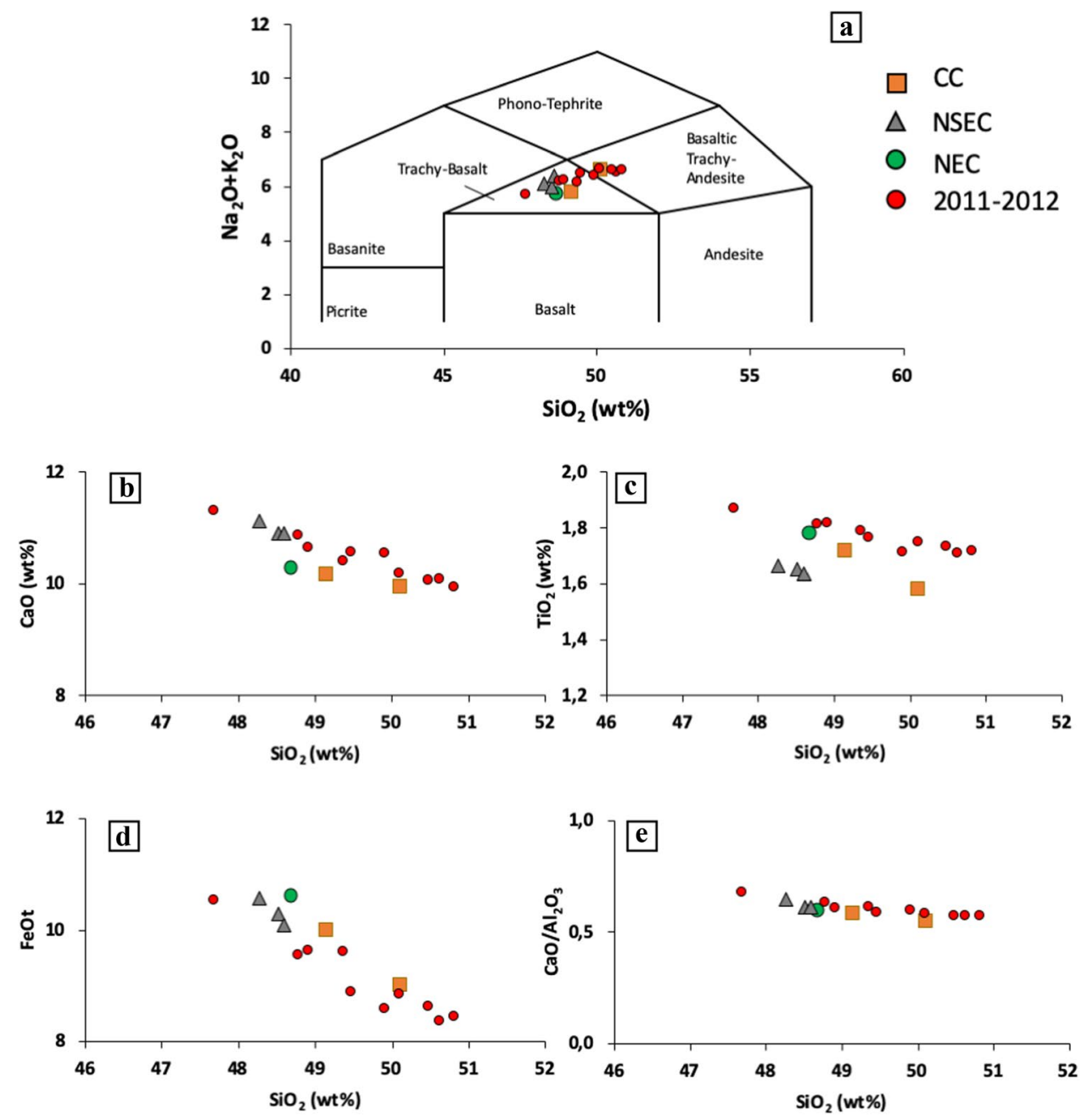

(Fig. 3b-e) suggest a similar differentiation trend mainly constrained by $\mathrm{Cpx}$ and Plg crystallization.

Primordial mantle-normalized trace element diagrams (Fig. 4, McDonough and Sun 1995) show the typical intraplate Etnean pattern (Peccerillo and Lustrino 2005; Ferlito et al. 2009; Giacomoni et al. 2018). All samples are characterized by a general enrichment in incompatible elements with negative anomalies in $\mathrm{K}, \mathrm{Rb}, \mathrm{Th}, \mathrm{Ta}$ and $\mathrm{Ti}$, and positive anomalies in $\mathrm{La}$, and $\mathrm{Nb}$.

\section{Discussion}

\section{Mineral-melt equilibrium conditions}

Equilibrium conditions between $\mathrm{Ol}, \mathrm{Cpx}$ and $\mathrm{Plg}$ and melt have been tested before applying the thermo-barometric equations, to investigate the dynamics of crystallization and magma mingling in highly dynamic open-conduit volcanic systems (Mollo et al. 2015; Giacomoni et al. 2018, Lanzafame et al. 2020).
According to previous studies on Mt. Etna's plumbing system (Giacomoni et al. 2016, 2018), near-equilibrium crystallization is generally attained between phenocryst cores and their host liquids (i.e. whole-rock analyses). Rationally, phenocrysts cores formed during the early stage of magma crystallization when magmatic conditions (i.e. low undercooling degree) are more favourable to allow progressive chemical re-equilibrium between crystal and hostmelt (Mollo et al. 2015; Giacomoni et al. 2018). In addition, the microcrystalline matrix of the samples rarely preserves analysable glass which is commonly too rich in $\mathrm{SiO}_{2}$ and alkaline elements to be representative of the magma composition. In the highly dynamic Mt. Etna open-conduit feeding systems, frequent cryptic mixing involving magmas with similar composition and $P-T-\mathrm{XH}_{2} \mathrm{O}$ conditions leads to the crystallization of outer crystal portions occurring under nonequilibrium conditions or, more realistically, in equilibrium with melt portions not represented by the whole-rock composition. For these reasons, we have initially tested equilibrium of $\mathrm{Ol}, \mathrm{Cpx}$ and $\mathrm{Plg}$ with their host whole-rock composition. In case of disequilibrium, crystals have been tested with 

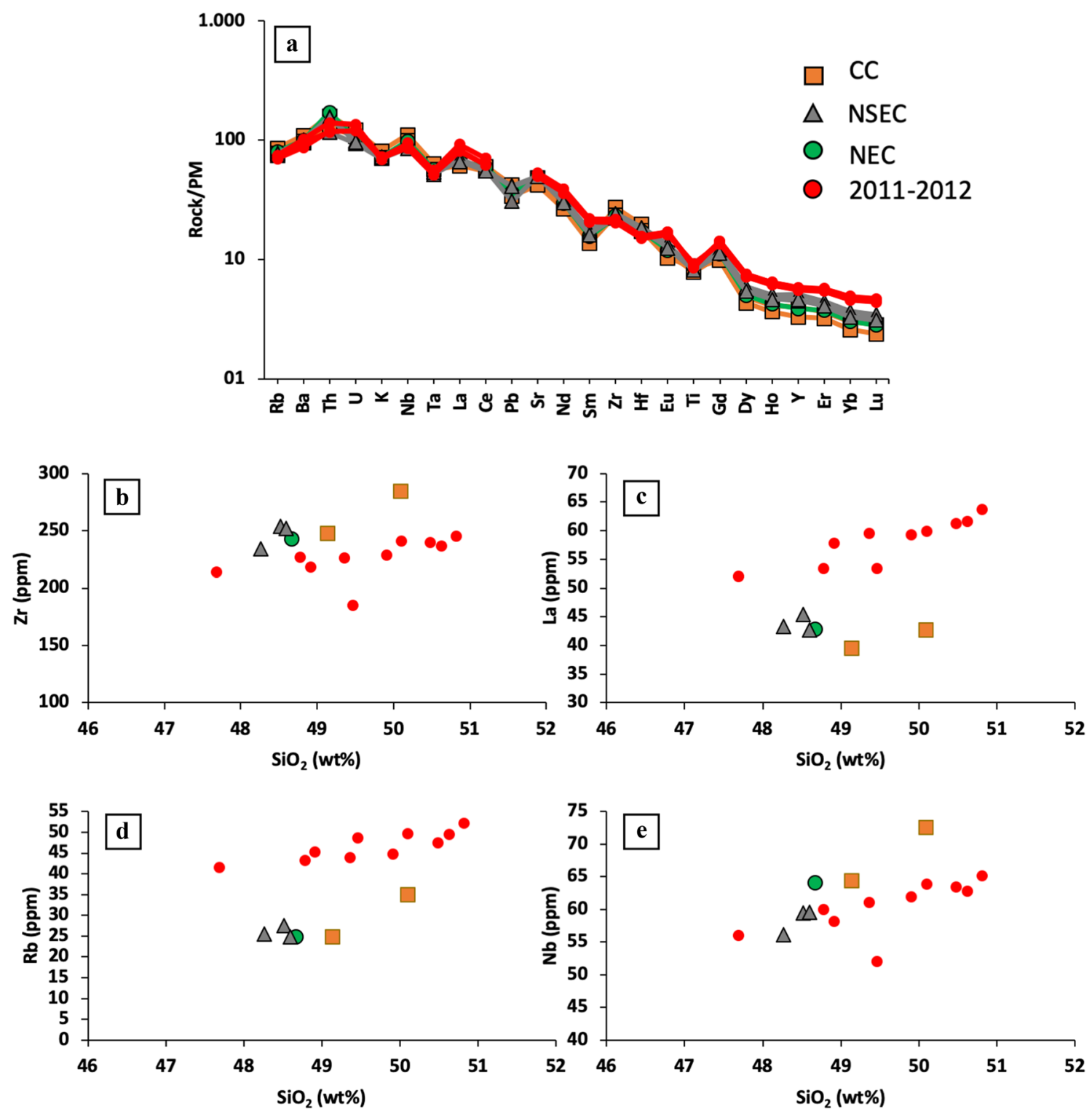

Fig. 4 Whole-rock trace elements geochemistry of studied products from the 2015 eruptive events compared with lava of 2011-2012 (red circles; Giacomoni et al. 2018). a Primordial mantle-normalized trace

more primitive or evolved melt compositions to obtain $\mathrm{P}-\mathrm{T}$ information about crystallization at greater depth.

The equilibrium crystallization of olivine has been verified through $\mathrm{Fe}-\mathrm{Mg}$ partitioning, which has a minor dependence on melt composition, $T, P$, and $f \mathrm{O}_{2}$, with an almost constant value of ${ }^{\text {ol-liq }} \mathrm{Kd}_{\mathrm{Fe}-\mathrm{Mg}}=0.30 \pm 0.03$ (Roeder and Emslie 1970; Mollo et al. 2015). The $\mathrm{Fe}^{2+} / \mathrm{Fe}^{3+}$ ratio of the melt is assumed to be close to 0.15 , as calculated from the equation of Kress and Carmichael (1991) by assuming an average oxygen fugacity between FMQ +1 and FMQ + 2 (Giacomoni et al. 2014). Most olivine from NSEC plots in a Fo range of Fo ${ }_{72.5-75.0}$ and is in equilibrium with the host rock, while several crystals with higher Fo (Fo $\left.{ }_{75-80}\right)$ are

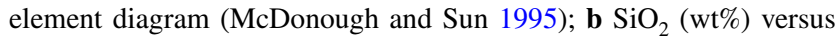
$\mathrm{Zr}(\mathrm{ppm}) ; \mathbf{c} \mathrm{SiO}_{2}(\mathrm{wt} \%)$ versus $\mathrm{La}(\mathrm{ppm}) ; \mathbf{d ~} \mathrm{SiO}_{2}$ (wt\%) versus $\mathrm{Rb}$ (ppm) and e $\mathrm{SiO}_{2}(\mathrm{wt} \%)$ versus $\mathrm{Nb}(\mathrm{ppm})$

not, and thus were reasonably formed in a more basic melt (Fig. 5a). NEC olivine presents a similar situation: equilibrium is obtained in the Fo ${ }_{72.9-75.7}$ range, while olivine with $\mathrm{Fo}_{76.5-78.9}$ are equilibrated with a more basic magma (Fig. 5a). Differently, only a small number of olivine crystals from $\mathrm{CC}$ with a restricted range of compositions ( $\mathrm{Fo}_{73.2-73.4}$ ) can be considered in equilibrium with the host magma. Most phenocrysts with $\mathrm{Fo}_{77.6-81.4}$ formed in a more basic magma while at Fo ${ }_{68.6-72.1}$ olivine would be equilibrated with a more differentiated melt (Fig. 5a).

Olivine crystals having ${ }^{\mathrm{ol}-\mathrm{liq}} \mathrm{Kd}_{\mathrm{Fe}-\mathrm{Mg}}<0.27$ have been traced back to equilibrium conditions using the composition of the products erupted during the 4/3/2012 eruptive 

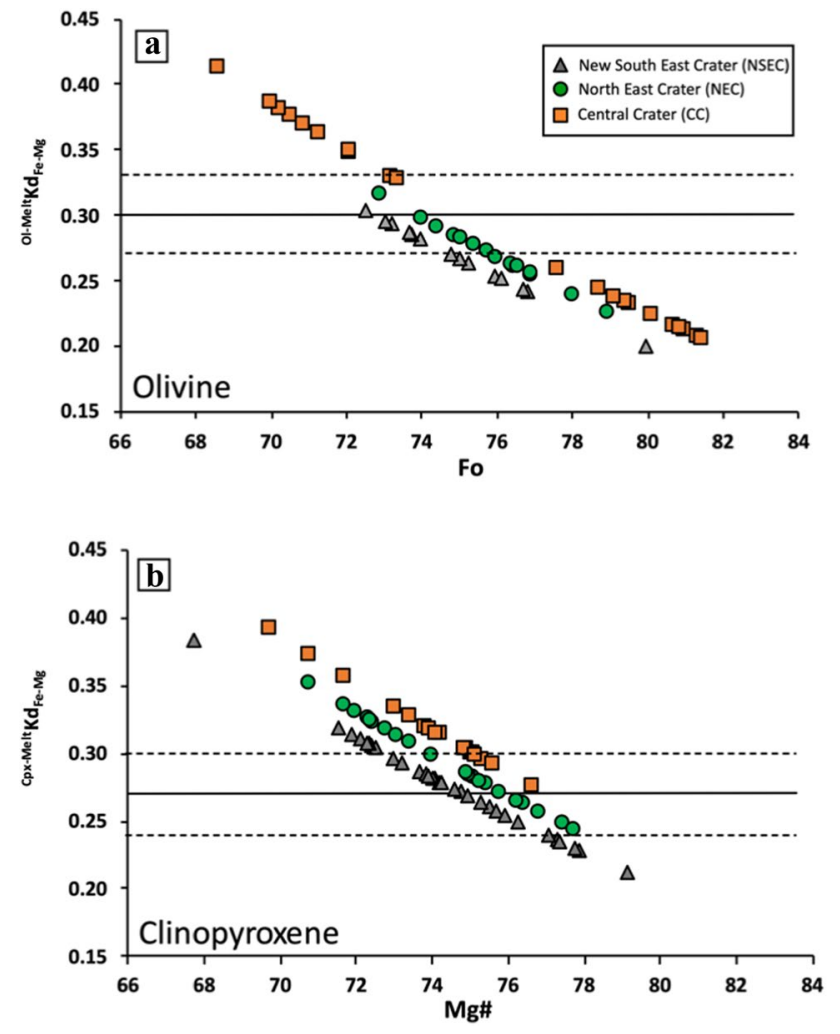

Fig. 5 Olivine (a) and Clinopyroxene (b) crystal-melt equilibrium conditions as ${ }^{\mathrm{Ol}-}$ meltKdMg-Fe versus forsterite $(\mathrm{Fo}){ }^{\mathrm{Cpx}-\mathrm{melt} \mathrm{Kd}} \mathrm{Mg}_{\mathrm{Mge}}$ ver-

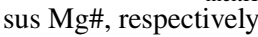

event (i.e. magma with $\mathrm{Mg} \#$ 51.5; Giacomoni et al. 2018) to obtain further information about the crystallization conditions of the deeper portion of the feeding system (Fig. 5a). Despite some geochemical differences between magma erupted during the 2012 and the 2015 activity, the composition of the lava erupted during the 4/3/2012 paroxysmal event represents the least evolved and temporally closest melt.

Conversely, equilibrium of clinopyroxene has been tested assuming ${ }^{\text {cpx }- \text { melt }} \mathrm{Kd}_{\mathrm{Fe}-\mathrm{Mg}}=0.27 \pm 0.03$, as indicated by Putirka et al. (2003). As with Ol, Cpx from NSEC and NEC contain several equilibrated phenocrysts in a range of $\mathrm{Mg} \#$ varying from 72.9 to 77.5 and from 74 to 77.7 , respectively (Fig. 5b). NSEC also contain a few crystals in equilibrium with both a more basic (Mg\# 77.2-79.1) and more evolved (Mg\# 67.7-72.5) melt, while phenocrysts not in equilibrium in NEC formed exclusively in a more evolved melt in a Mg\# range of 70.7-73.4. CC Cpx find themselves in equilibrium in a $\mathrm{Mg} \#$ range between 74.9 and 79.1, while some crystals (79.1-81.5) formed in a more primitive melt. However, the majority (69.7-74.8) were equilibrated with a more evolved magma (Fig. 5b).

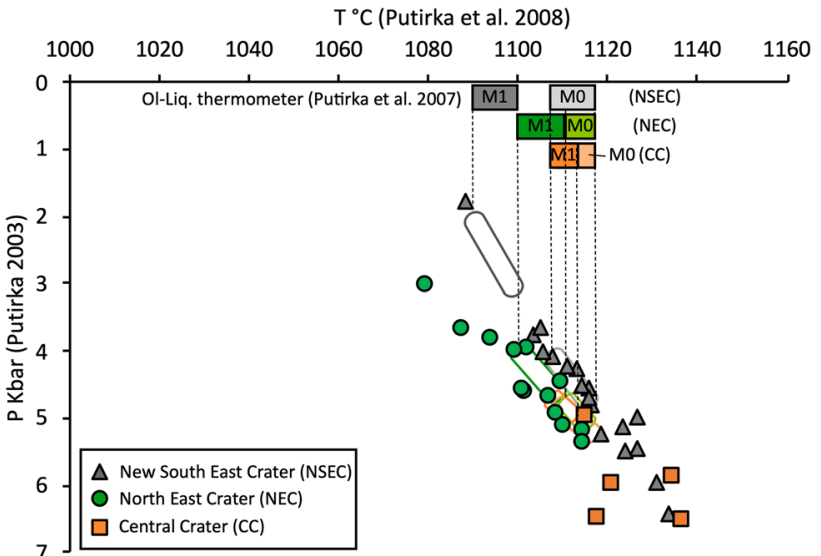

Fig. 6 Clinopyroxene- and olivine-melt thermometers (Putirka 2008, Eq. 33 and Putirka et al. 2007) and clinopyroxene-melt barometer (Putirka et al. 2003) of studied samples. M0 are olivine phenocrysts in equilibrium with the 4/3/2012 less evolved magma composition; M1 are olivine in equilibrium with their host magma composition

\section{P-T crystallization conditions}

The crystallization temperature of olivine has been estimated by means of the Putirka et al. (2007) equation, which yields an error of $\pm 25^{\circ} \mathrm{C}$; calculation was performed assuming $4 \mathrm{wt} \%$ of $\mathrm{H}_{2} \mathrm{O}$ in the melt, in accordance with recent studies concerning Mt. Etna melt inclusions by Gennaro et al. (2018) and Giacomoni et al. (submitted). Results show that olivine phenocrysts in equilibrium with NSEC host rock form in a range of temperatures from 1092 to $1100{ }^{\circ} \mathrm{C}$. Olivine from NEC and CC are equilibrated at a higher $T$, ranging from 1100 to $1111^{\circ} \mathrm{C}$ and from 1108 to $1111^{\circ} \mathrm{C}$ respectively. Olivine crystals with ${ }^{\mathrm{Ol}-\mathrm{Liq}} \mathrm{Kd}_{\mathrm{Fe}-\mathrm{Mg}}<0.27$, traced back to equilibrium with the $4 / 3 / 2012$ melt composition yield crystallization $\mathrm{T}$ ranging from 1109 to $1117^{\circ} \mathrm{C}$ in NSEC, from 1107 to $1117^{\circ} \mathrm{C}$ NEC and from 1104 to $1113^{\circ} \mathrm{C} \mathrm{CC}$.

Crystallization temperatures and pressure of clinopyroxene have been determined by means of the mineralmelt exchange reactions of diopside/hedenbergite-jadeite and hedenbergite/Ca-Tschermak as reappraised by Putirka (2008). The temperature has been estimated through geothermometer Eq. 33 (Putirka 2008) which has the advantage of being pressure independent with an estimated error of $\pm 25^{\circ} \mathrm{C}$. Resulting temperature was then applied as input data to determine the crystallization pressure by means of the Putirka et al. (2003) equation with an error of $\pm 170 \mathrm{MPa}$.

Results indicate that NSEC clinopyroxene formed in a range of pressure and temperatures from $640 \mathrm{MPa}$ at $1134{ }^{\circ} \mathrm{C}$ to $180 \mathrm{MPa}$ at $1088^{\circ} \mathrm{C}$. These data clearly differ from those obtained by NEC and CC phenocrysts which formed from $550 \mathrm{MPa}$ at $1102{ }^{\circ} \mathrm{C}$ to $30 \mathrm{MPa}$ at $1067^{\circ} \mathrm{C}$ and from $650 \mathrm{MPa}$ at $1122^{\circ} \mathrm{C}$ to $4.7 \mathrm{MPa}$ at $1104{ }^{\circ} \mathrm{C}$ (Fig. 6). 


\section{The December 2015 feeding system}

Petrographic, geochemical and thermo-barometric constraints from the 2015 activity, in comparison with the previous paroxysmal events of 2011-2012 (Giacomoni et al. 2018), provide new insights on the physico-chemical conditions of magma and on the occurrence of pre-eruptive mixing and ascent dynamics.

The whole-rock geochemistry and petrographic features of products emitted during the December 2015 paroxysmal activity do not show significant differences from the highly porphyritic lavas commonly emitted during summit and sub-terminal activity of Mt. Etna. Samples erupted from the NSEC craters present a slightly more basic composition with respect to CC and NEC. However, both major variation diagrams and trace element concentration seems to indicate a common liquid line of descent, dominated by fractional crystallization of $\mathrm{Ol}+\mathrm{Cpx}$. However, compositional differences in $\mathrm{TiO}_{2}, \mathrm{Zr}$, La, $\mathrm{Rb}$ seems to exclude the 4/3/2012 magma composition as the primary end member, suggesting a major magma replenishment in the deepest portion of the feeding system prior to the onset of the event.

Consequently, observed differences in composition must be ascribed to crystallization conditions and differentiation processes en-route to the surface, likely at a shallow crustal depth. Results from crystal-melt equilibrium and thermobarometry of olivine and clinopyroxene allow us to delineate some distinct features of the plumbing system of the 2015 activity and to confirm some observations made by studying the previous 2011/2012 paroxysms.

Clinopyroxene thermo-barometry suggests that magma crystallized continuously during the ascent toward the surface from $\sim 600 \mathrm{MPa}$ in a range of temperature from 1140 to $1104{ }^{\circ} \mathrm{C}$ (Fig. 6). These conditions are consistent with the cpx liquidus temperature on the cotectic with olivine in a hydrated $\left(4 \mathrm{wt} \% \mathrm{H}_{2} \mathrm{O}\right)$ melt as determined by RhyoliteMELTS modelling, but far from the estimated ol liquidus conditions $\left(1220{ }^{\circ} \mathrm{C}\right)$. This observation, together with the overall slightly evolved composition of whole rock, indicate that the mineral assemblage of studied lavas limits our ability to obtain information regarding magmatic crystallization at pressures higher than $600 \mathrm{MPa}(<22 \mathrm{~km}$ b.s.l. $)$. On the other hand, from this depth toward the surface, we can reasonably consider the feeding system as vertically extended without significant magma chambers or ponding zones (Giacomoni et al. 2014, 2018).

Since the cpx and ol should have formed along a cotectic line at the estimated T-P conditions, we have extrapolated the pressure of crystallization of olivine following the method described in Giacomoni et al. (2018). As shown in Fig. 6, olivine in equilibrium with the whole rock (M1 facies, Giacomoni et al. 2018) formed in a range of pressures between $500 \mathrm{MPa}$ to $450 \mathrm{Kbar}(\mathrm{CC})$ and between 500 and $400 \mathrm{MPa}$ (NEC). Conversely, the NSEC M1 olivines equilibrated at significantly lower pressures, between 200 and $300 \mathrm{MPa}$. Olivine crystals re-equilibrated with the 4/3/2012 more primitive magma composition (M0) equilibrated between 480 and $500 \mathrm{MPa}$ (NEC), 470-510 MPa (CC) and between 380 and $470 \mathrm{MPa}$ (NSEC).

These results, together with data from the 2011-2012 eruptions, have been plotted in P-T space (Fig. 7) obtained by means of Rhyolite-MELTS software (version 1.2.0; Gualda et al. 2012); thermodynamic calculations were made starting from a mantle-equilibrated magma composition from the 2006 eruption (Giacomoni et al. 2014) at $4 \mathrm{wt} \%$ $\mathrm{H}_{2} \mathrm{O}$ at constant $f \mathrm{O}_{2}$ equal to $\mathrm{FMQ}+1.5$. Since plagioclase is not stable at these conditions above $800{ }^{\circ} \mathrm{C}$, to visualize its stability field and to interpret the recognized textures and compositional zoning, plagioclase stability was determined starting from the NSEC trachybasaltic composition at decreasing $\mathrm{H}_{2} \mathrm{O}$ content from 3 to $1 \mathrm{wt} \%$ (Figs. 7, 8). Each calculation run was performed at equilibrium crystallization mode, starting from a constant pressure and decreasing the temperature from the $T_{\text {liquidus }}$ to $1000^{\circ}$. The $\mathrm{H}_{2} \mathrm{O}$ solubility threshold was obtained in accordance with the model of Papale (1999) and the stratigraphic column after the seismic and geologic studies of Finetti (2005).

Rhyolite-MELTS modelling indicates that the mantleequilibrated (mg\#68) magma with $4 \mathrm{wt} \%$ of dissolved $\mathrm{H}_{2} \mathrm{O}$ reached the liquidus with olivine in equilibrium at Fo88 at $\sim 1250{ }^{\circ} \mathrm{C}$ at lithospheric mantle depth. Olivine with comparable Fo contents are rarely found in recent products, but some crystals do occasionally occur such as those found in the 2011-2012 eruptive events (Giacomoni et al. 2018). Magma keeps crystallizing and fractionating olivine $(\sim 10 \%$, Giacomoni et al. 2014 and 2018) during its route through the lithospheric mantle, reaching Ol-Cpx cotectic stability at $\sim 1150^{\circ} \mathrm{C}$ at $700 \mathrm{MPa}$, corresponding to the $\mathrm{MOHO}$ depth as stated by Finetti (2005). Cotectic $\mathrm{Ol}$ in these $T-P$ conditions should vary in Fo content from 84 to 78 (M0 group of 2011-2012). From this depth, the P-T ascent path of magma inside is tracked by Cpx crystallization; this represents an ascent rate of 9.4 and $7.5 \mathrm{MPa} /{ }^{\circ} \mathrm{C}$, respectively, along a liquidus line constrained by $3 \mathrm{wt} \%$ to $4.8 \mathrm{wt} \%$ of dissolved $\mathrm{H}_{2} \mathrm{O}$ for the 2011-2012 and 2015 magmas. However, if Cpx apparently tracks an almost continuous crystallization from 700 to $200 \mathrm{MPa}, \mathrm{Ol}$ compositions change discretely (Kahl et al. 2011; Giacomoni et al. 2018). A plausible explanation for this apparent discrepancy could reside in the faster interdiffusion of $\mathrm{Fe}-\mathrm{Mg}$ in $\mathrm{Ol}$ which tend to erase most small micrometrical compositional zoning (Dohmen et al. 2007). Conversely, Cpx complex zoning is more easily preserved and thus tracks a more continuous magma ascent path. However, Ol compositional grouping provides some important information on the dynamics of magma ascent along central conduits, as well as eventual emission from different summit 
Fig. $7 \quad P-T$ path of magma ascent resulting from thermobarometric calculation superimposed to a stability phase diagram by means of RhyoliteMELTS simulations at constant FMQ + 1 fugacity. $\mathrm{H}_{2} \mathrm{O}$ exsolution surface at 4 (wt \%) constant composition has been obtained applying the solubility model of Papale (1999). $P-T$ crystallization conditions of clinopyroxene and olivine of the 2011-2012 eruptive events are also showed for comparison while crustal stratigraphy refers to results from Finetti (2005)

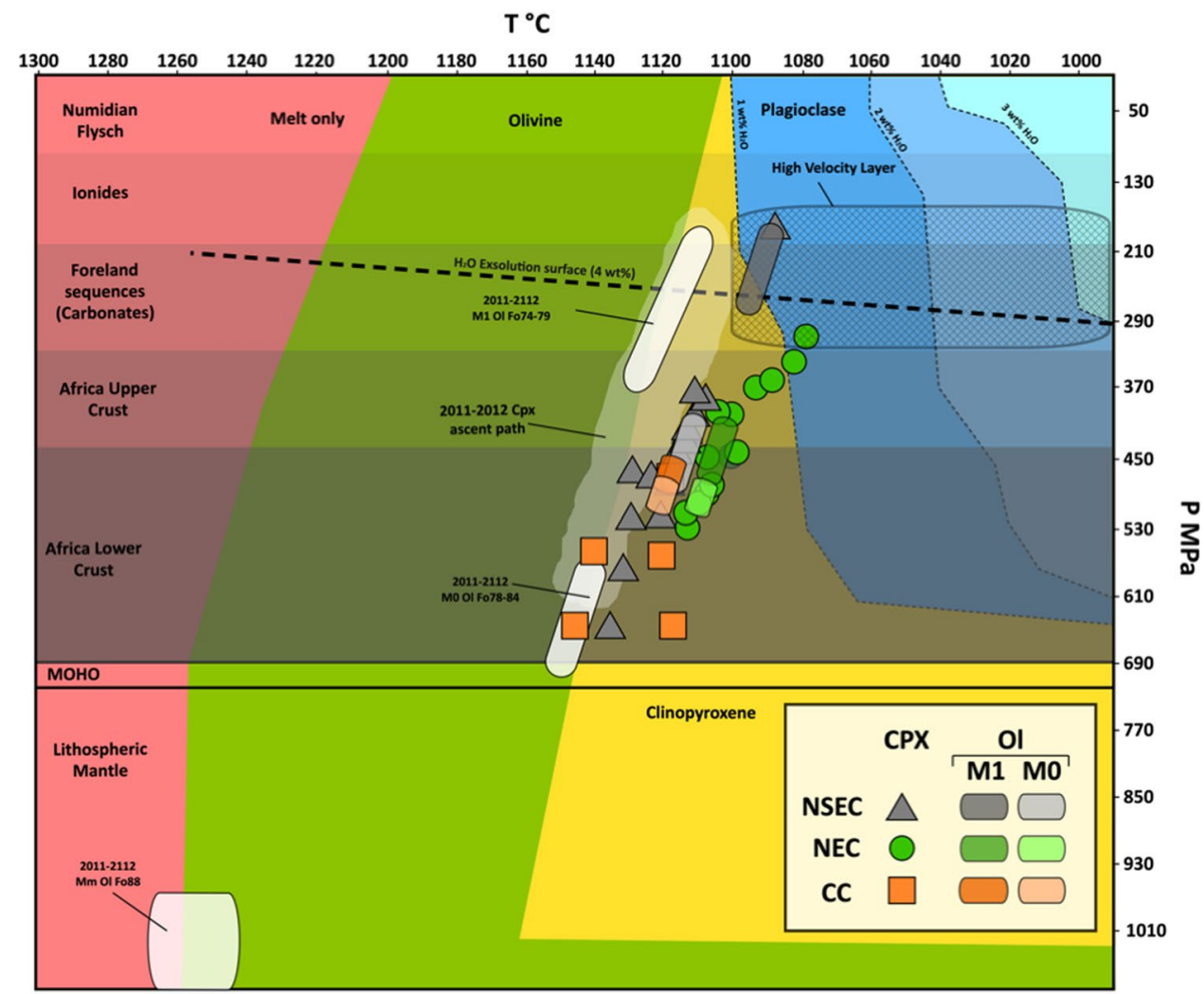

craters. M1 Ol phenocrysts, in equilibrium with the erupted magma composition, erupted during 2011-2012 and 2015 from NSEC and equilibrated at a significantly lower pressure than those recognized in NEC and CC in 2015 samples. This could be interpreted as a significantly shallower depth of the magma column below the NSEC, thus suggesting that the final magma ascent path differs from those of NEC and CC.

A soon as the magma column reaches the $\mathrm{H}_{2} \mathrm{O}$ saturation depth, degassing and undercooling promote the stability and crystallization of plagioclase (Mollo et al. 2015; Giacomoni et al. 2014). In accordance with the estimated $P-T$ ascent path, this occurs at $\sim 280 \mathrm{MPa}$ inside the foreland carbonate sequence (Finetti 2005). The stratigraphic positioning of plagioclase appearance is also in agreement with the depth of "High Velocity Layer" confirmed by several geophysical studies (DeGori et al. 2005; Patanè et al. 2006) and could be interpreted as a rigid cumulitic gabbroic assemblage. The Rhyolite-MELTS thermodynamic plagioclase stability model allows us to interpret the recognized dissolutionregrowth texture (Fig. 8). Plagioclase stability is strongly constrained by $\mathrm{H}_{2} \mathrm{O}$ content and An content increases with $T, \mathrm{H}_{2} \mathrm{O}$ and decreases with $P$ (Tsuchiyama 1985; Humphreys et al. 2006; Viccaro et al. 2010; Giacomoni et al. 2014). Rhyolite-MELTS modelling (Fig. 8) suggest that an $\mathrm{An}_{88-80}$ plagioclase core could have formed at $1040-1030{ }^{\circ} \mathrm{C}$ at 290-200 MPa in a magma with $2.2 \mathrm{wt} \%$ of dissolved $\mathrm{H}_{2} \mathrm{O}$ (Fig. 8a crystal zone 1), as confirmed by the Waters and
Lange (2015) hygrometer. Since Rhyolite-MELTS modelling does not simulate disequilibrium crystallization during degassing, these estimated $\mathrm{T}$ should be interpreted as crystallization $\mathrm{T}$ under strong undercooling process (and not as the $\mathrm{T}$ of the melt). The de-hydration of the melt is indispensable to allow plagioclase crystallization (Humphreys et al. 2006; Giacomoni et al. 2014), as the relatively fast and steady ascent ratio of magma does not allow a significant $\mathrm{T}$ drop due to the slow heat diffusion towards the surrounding rocks. Two main processes could promote volatile exsolution and consequent plagioclase crystallization: decompression and $\mathrm{CO}_{2}$ flushing. Decompression is a well-studied process that can induce magmatic crystallization especially in a volatile-saturated melt (Hammer and Rutherford 2002; Mollard et al. 2012). Alternatively, a $\mathrm{CO}_{2}$-rich volatile fluid phase exsolved in a deeper portion of the plumbing system and flushing the shallower part of the magmatic column could promote $\mathrm{H}_{2} \mathrm{O}$ exsolution and crystallization without significant magmatic volume transfer (Riker et al. 2015; Caricchi et al. 2018).

Early formed An-rich cores often present a rounded edge followed by a less calcic $\left(\mathrm{An}_{70-52}\right)$ overgrowth (Fig. 8a, crystal zone 2). The process responsible for this plagioclase destabilization is a "simple dissolution" response occurring when plagioclase reacts with a melt that is undersaturated in the plagioclase phase (Tsuchiyama 1985; Giacomoni et al. 2014). The most common 
Fig. 8 Rhyolite-MELTS plagioclase stability $\mathrm{P}-\mathrm{T}$ conditions at constant FMQ + 1 fugacity; clinopyroxene and olivine ascent path has been simplified from Fig. 7. $\mathrm{H}_{2} \mathrm{O}$ exsolution surface at 4 (wt \%) constant composition has been obtained applying the solubility model of Papale (1999). P Plagioclase liquidus $P-T$ lines modelled at 1,2 and 3 (wt\%) of dissolved $\mathrm{H}_{2} \mathrm{O}$ in the melt. Squared SEM microphotograph show typical dissolved core (a) and dusty rim (b) plagioclases which can be explained as formed in in $P-T$ conditions (1) and (2), respectively, due to mixing or volatile flushing. (See text for detailed description)

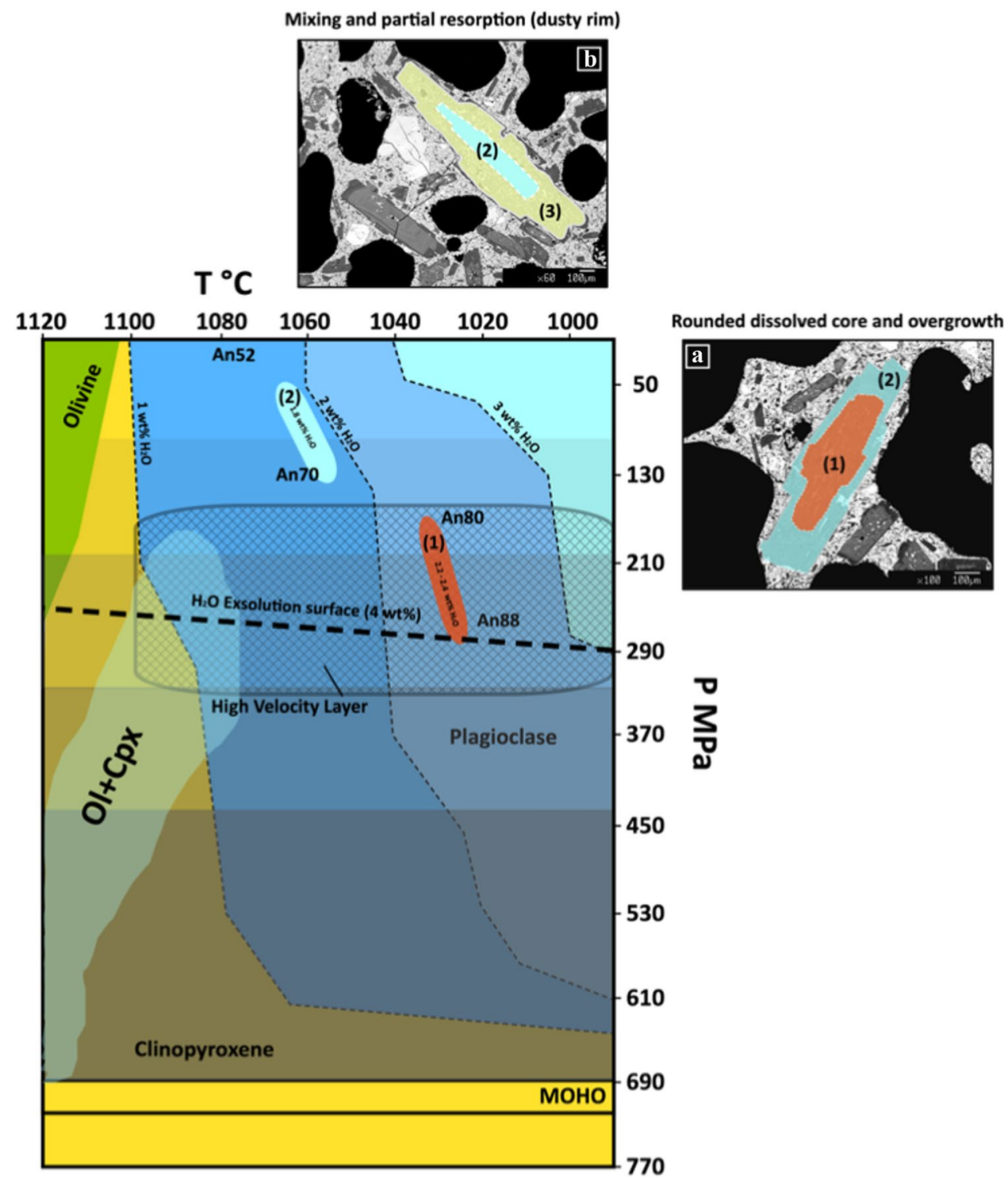

magmatic process that could cause such disequilibrium is the increasing in $\mathrm{H}_{2} \mathrm{O}$ content in the melt due to mixing/ mingling with a basic incoming magma with its pristine $4 \mathrm{wt} \%$ of dissolved $\mathrm{H}_{2} \mathrm{O}$ or, as recently hypothesised, by flushing of volatile $\mathrm{H}_{2} \mathrm{O}$-rich fluids (Ferlito et al. 2010, 2014; Ferlito 2017). In fact, the $\mathrm{H}_{2} \mathrm{O} / \mathrm{CO}_{2}$ ratio of the exsolved fluid increases as $\mathrm{CO}_{2}$-rich fluids are progressively extracted and migrate upward. Since the magma in the flushed shallower magma has been gradually enriched in $\mathrm{CO}_{2}$ and depleted in $\mathrm{H}_{2} \mathrm{O}$, it re-equilibrates by exsolving $\mathrm{CO}_{2}$ and incorporating $\mathrm{H}_{2} \mathrm{O}$. Although this concept still requires further investigation and numerical modelling, it is comparable with that described by Caricchi et al (2018) and hypothesized by Ferlito et al. (2014). Rhyolite-MELTS modelling suggests that after dissolution, plagioclase growth resumes at shallower depth due to decompression and further magma volatilization, between 130 and $50 \mathrm{MPa}$.

The second type of plagioclase is instead characterized by a core with low calcic composition $\left(\mathrm{An}_{70-52}\right.$; Fig. $8 \mathrm{~b}$ zone 2), analogous to the outer zone of the first type, surrounded by an anorthitic dusty rim $\left(\mathrm{An}_{88-80}\right.$; Fig. 8 zone 3$)$. Dusty rims have been experimentally reproduced after a "partial dissolution" reaction between the pre-existing low calcic phenocryst with a melt in which a more anorthitic plagioclase is stable (hotter or more $\mathrm{H}_{2} \mathrm{O}$-rich Tsuchiyama 1985). Since Rhyolite-MELTS, hygrometers and volatile solubility models indicate that $\mathrm{An}_{70-52}$ cores are stable in a magma with $1.8 \mathrm{wt} \%$ of dissolved $\mathrm{H}_{2} \mathrm{O}$, they should have formed at significant shallower depth with respect to the previously described An88-80 plagioclases. In accordance with the solubility model of Ghiorso and Gualda (2015), feasible 
stability conditions are reached between 130 and $50 \mathrm{MPa}$, suggesting that both magma mingling and $\mathrm{H}_{2} \mathrm{O}$-flushing could have been responsible for triggering an eruption.

\section{Concluding remarks}

The petrologic and thermo-barometric study of the December 2015 eruptive event has contributed to improving our knowledge of the vertically continuous feeding system of Mount Etna, which had been already illuminated thanks to the paroxysmal activity of 2011-2012 (Giacomoni et al. 2018).

Thermo-barometric estimates and Rhyolite-MELTS modelling indicate that (1) primary volatile-rich magma crosses its liquidus $T\left(\sim 1250{ }^{\circ} \mathrm{C}\right)$ at $\sim 1 \mathrm{GPa}$, (2) formed $\mathrm{Ol}$ phenocrysts (Fo88) keep re-equilibrating during magma ascent, reaching iii) the Ol-Cpx cotectic $T\left(\sim 1150{ }^{\circ} \mathrm{C}\right)$ at $\sim 700 \mathrm{MPa}$. $\mathrm{Ol}$ crystal equilibrium conditions of the NSEC crater differ significantly from those of the CC and the NEC, indicating a shallower depth of the magmatic column which fed the eruption at NSEC. However, Ol phenocrysts suggest that each crater was subject to a deep magmatic recharge between 530 and $440 \mathrm{MPa}$.

Finally, $\mathrm{Plg}$ stability is strongly constrained by the $\mathrm{H}_{2} \mathrm{O}$ / $\mathrm{CO}_{2}$ of the melt. According to Rhyolite-MELTS simulations, the great majority of $\mathrm{An}_{88-80}$ plagioclases are in equilibrium with a magma with $2.2 \mathrm{wt} \%$ of dissolved $\mathrm{H}_{2} \mathrm{O}$, at 290-200 MPa. However, $\mathrm{CO}_{2}$ flushing could be an efficient process to promote $\mathrm{H}_{2} \mathrm{O}$ exsolution and consequent Plg crystallization at greater depth. Similarly, the increase of the $\mathrm{H}_{2} \mathrm{O} / \mathrm{CO}_{2}$ ratio of the flushing fluid in an almost steady-state vertical conduit regime could have a deep effect on the stability of crystallized phenocrysts, inducing crystal dissolution and resorption without significant magma volume transfer and therefore worthy of further, more focused studies.

Acknowledgements This study was made possible through financial support from MIUR-PRIN Project 2017 "Micro to Macro-How to unravel the nature of the Large Magmatic Events". The authors are grateful to Alexander Bolam for revising the English text.

Funding Open access funding provided by Università degli Studi di Ferrara within the CRUI-CARE Agreement.

Open Access This article is licensed under a Creative Commons Attribution 4.0 International License, which permits use, sharing, adaptation, distribution and reproduction in any medium or format, as long as you give appropriate credit to the original author(s) and the source, provide a link to the Creative Commons licence, and indicate if changes were made. The images or other third party material in this article are included in the article's Creative Commons licence, unless indicated otherwise in a credit line to the material. If material is not included in the article's Creative Commons licence and your intended use is not permitted by statutory regulation or exceeds the permitted use, you will need to obtain permission directly from the copyright holder. To view a copy of this licence, visit http://creativecommons.org/licenses/by/4.0/.

\section{References}

Aloisi M, Bonaccorso A, Cannavò F, Gambino S, Mattia M, Puglisi G, Boschi E (2009) A new dike intrusion style for the Mount Etna May 2008 eruption modelled through continuous tilt and GPS data. Terra Nova 21:316-321

Andronico D, Scollo S, Cristaldi A, Caruso S (2008) The 2002-2003 Etna explosive activity: tephra dispersal and features of the deposit. J Geophys Res Solid Earth 113:B04209. https://doi.org/ 10.1029/2007JB005126

Armienti P, Innocenti F, Petrini R, Pompilio M, Villari L (1988) Subaphyric alkali basalt from Mt. Etna: inferences on the depth and composition of the source magma. Rend Soc Ital Miner Pet 43:877-891

Behncke B, Branca S, Corsaro RA, De Beni E, Miraglia L, Proietti C (2014) The 2011-2012 summit activity of Mount Etna: birth, growth and products of the new SE crater. J Volcanol Geotherm Res 270:10-21

Branca S, and Del Carlo P (2004) Eruptions of Mt. Etna during the past 3200 years: a revised compilation integrating the historical and stratigraphic records, in Mt. Etna: Volcano Laboratory. In: Bonaccorso A et al. (eds) Geophys Monograph, vol 143. AGU, Washington, DC, pp 1-27

Cannata A, Di Grazia G, Giuffrida M, Gresta S, Palano M, Sciotto M, Viccaro M, Zuccarello F (2018) Space-time evolution of magma storage and transfer at Mt Etna volcano (Italy): the 2015-2016 reawakening of voragine crater. Geochem Geophys Geosyst. https://doi.org/10.1002/2017GC007296

Caricchi L, Sheldrake TE, Blundy J (2018) Modulation of magmatic processes by $\mathrm{CO}_{2}$ flushing. Earth Planet Sci Lett 491:160-171

Casetta F, Giacomoni PP, Ferlito C, Bonadiman C, Coltorti M (2019) The evolution of the mantle source beneath Mt. Etna (Sicily, Italy): from the $600 \mathrm{ka}$ tholeiites to the recent trachybasaltic magmas. Int Geol Rev. https://doi.org/10.1080/00206814.2019. 1610979

Corsaro RA, Pompilio M (2004) Buoyancy-controlled eruption of magmas at Mount Etna. Terra Nova 16:16-22

Corsaro RA, Civetta L, Di Renzo V, Miraglia L (2009a) Petrology of lavas from the 2004-2005 flank eruption of Mt. Etna, Italy: inferences on the dynamics of magma in the shallow plumbing system. Bull Volcanol 71:781-793

Corsaro RA, Andronico D, Behncke B, Branca S, Caltabiano T, Ciacnitto F, Cristaldi A, De Beni E, La Spina A, Lodato L, Miraglia L, Neri M, Salerno G, Scollo C, Spata G (2017) Monitoring the December 2014 summit eruptions of Mt. Etna (Italy): implications on the eruptive dynamics. J Volcanol Geotherm Res 341:53-69

Corsaro RA, Metrich N, Allard P, Andronico D, Miraglia L, Fourmentraux C (2009b) The 1974 flank eruption of Mount Etna: an archetype for deep dike-fed eruptions at basaltic volcanoes and a milestone in Etna's recent history. J Geophys Res. https://doi. org/10.1029/2008JB006013

De Beni E, Behncke B, Branca S, Nicolosi I, Carluccio R, Caracciolo D, Ajello F, Chiappini M (2005) The continuing story of Etna's New Southeast Crater (2012-2014): evolution and volume calculations based on field surveys and aerophotogrammetry. J Volcanol Geotherm Res 303:175-186

De Gori P, Chiarabba C, Patanè D (2005) Qp structure of Mt Etna: constraints for the physics of the plumbing system. J Geophys Res. https://doi.org/10.1029/2003JB002875 
Di Grazia G, Falsaperla S, Langer H (2006) Volcanic tremor location during the 2004 Mount Etna lava effusion. Geophys Res Lett 33:L04304

Dohmen R, Becker HW, Chakraborty S (2007) Fe-Mg diffusion in olivine I: experimental determination between 700 and $1200^{\circ} \mathrm{C}$ as a function of composition, crystal orientation and oxygen fugacity. Phys Chem Min 34:389-407

Ferlito C (2017) Mout Etna volcano (Italy). Just a giant hot spring. Earth Sci Rev 177:14-23

Ferlito C, Coltorti M, Cristofolini R, Giacomoni PP (2009) The contemporaneous emission of low- $\mathrm{K}$ and high- $\mathrm{K}$ trachybasalts and the role of the NE rift during the 2002 eruptive event, Mt. Etna. Italy Bull Volcanol 71:575-587

Ferlito C, Viccaro M, Nicotra E, Cristofolini R (2010) Relationship between the flank sliding of the south east crater (Mt. Etna, Italy) and the paroxysmal event of November 16, 2006. Bull Volcanol 72:1179-1190

Ferlito C, Coltorti M, Lanzafame G, Giacomoni PP (2014) The volatile flushing triggers eruptions at open conduit volcanoes: evidence from Mount Etna volcano (Italy). Lithos 184-187:447-455

Finetti IR (2005) Depth contourmap of the Moho discontinuity in the central Mediterranean region from new crop seismic data. In: Finetti IR (ed) CROP PROJECT. Deep seismic exploration of the Central Mediterranean and Italy, pp 597-606

Gennaro E, Iacono-Marziano G, Paonita A, Rotolo SG, Martel C, Rizzo AL, Pichavant M, Liotta M (2018) Melt inclusions track melt evolution and degassing of Etnean magmas in the last $15 \mathrm{ka}$. Lithos 324-325:716-732

Ghiorso MS, Gualda GAR (2015) An $\mathrm{H}_{2} \mathrm{O}-\mathrm{CO}_{2}$ mixed fluid sarturation model compatible with rhyolite-MELTS. Contrib Miner Pet. https://doi.org/10.1007/s00410-015-1141-8

Giacomoni PP, Ferlito C, Alesci G, Coltorti M, Monaco C, Viccaro M, Cristofolini R (2012) A common feeding system of the NE and S rifts as revealed by the bilateral 2002/2003 eruptive event at Mt. Etna (Sicily, Italy). Bull Volcanol 74:2415-2433

Giacomoni PP, Ferlito C, Coltorti M, Bonadiman C, Lanzafame G (2014) Plagioclase as archive of magma ascent dynamics on "open conduit" volcanoes: the 2001-2006 eruptive period at Mount Etna. Earth Sci Rev 138:371-393

Giacomoni PP, Coltorti M, Mollo S, Ferlito C, Braiato M, Scarlato P (2018) The 2011-2012 paroxysmal eruptions at Mt. Etna volcano: Insights on the vertically zoned plumbing system. J Volcanol Geotherm Res 349:370-391

Giacomoni PP, Coltorti M, Bryce J, Fahnestock F, Guitreau M (2016) Mt Etna plumbing system revealed by combined textural, compositional and thermobarometric studies in clinopyroxene. Contrib Miner Pet. https://doi.org/10.1007/s00410-016-1247-7

Gillot PY, Kieffer G, Romano R (1994) The evolution of Mount Etna in the light of potassium-argon dating. Acta Volcanol 5:81-87

Gualda GAR, Ghiorso MS, Lemons RV, Carley TL (2012) RhyoliteMELTS: o modified calibration of MELTS optimized for a SilicaRich, fluid-bearing magmatic systems. J Pet 33:875-890

Hammer JE, Rutherford MJ (2002) An experimental study of the kinetics of decompression-induced crystallization in silicic melt. J Geophys Res. https://doi.org/10.1029/2001JB000281

Hirn A, Nicolich R, Gallart J, Laigle M, and ETNASEIS Scientific Group (1997) Roots of Etna volcano in faults of great earthquakes. Earth Planet Sci Lett 148:171-191

Humphreys MCS, Blundy JD, Sparks RSJ (2006) Magma evolution and open-system processes at Shiveluch volcano: insights from phenocrysts zoning. J Pet 47:2303-2334

Kahl M, Chakraborty S, Costa F, Pompilio M (2011) Dynamic plumbing system beneath volcanoes by kinetic modelling, and the connection to monitoring data: an example from Mt. Etna Earth Planet Sci Lett 308:11-22
Kahl M, Chakraborty S, Costa F, Pompilio M, Liuzzo M, Viccaro M (2013) Compositionally zoned crystals and real-time degassing data reveal changes in magma transfer dynamics during the 2006 summit eruptive episodes of Mt. Etna Bull Volcanol 75:692

Kieffer G (1975) Pillows and hyaloclastites associated to subaerial lavas at the southwest of the base of Mount Etna (Sicily, Italy). Geol Mediter 77:179-184

Kress VC, Carmichael ISE (1991) The compressibility of silicate liquids containing $\mathrm{Fe}_{2} \mathrm{O}_{3}$ and the effect of composition, temperature, oxygen fugacity and pressure on their redox states. Contrib Miner Pet 108:82-92

Lanzafame G, Casetta F, Giacomoni PP, Donato S, Mancini L, Coltorti M, Ntaflos T, Ferlito C (2020) The Skaros effusive sequence at Santorini (Greece): Petrological and geochemical constraints on an interplinian cycle. Lithos 362-363:05504

Le Maitre R (2002) Igneous rocks: a classification and glossary of terms. Cambridge University Press, Cambridge

Lentini F, Carbone S, Guarnieri P (2006) Collisional and post-collisional tectonics of the Appenninic-Maghrebian orogen (southern Italy). Geol Soc Am 409:57-89

McDonough WF, Sun SS (1995) The composition of the Earth. Chem Geol 120:223-253

Metrich N, Rutherford MJ (1998) Low pressure crystallization paths of $\mathrm{H}_{2} \mathrm{O}$-saturated basaltic-hawaiitic melts from Mt. Etna: implications for open-system degassing volcanoes. Geochim Cosmochim Acta 62:1195-1205

Micallef A, Camerlenchi A, Georgiopoulou A, Garcia-Castellanos D, Gutscher MA, Lo Iacono C, Huvenne VAI, Mountjoy JJ, Paull CK, La Bas T, Spatola D, Facchin L, Accettella D (2018) Geomorphic evolution of the Malta Escarpment and implicaitons for the Messinian evaporative drawdown in the eastern Mediterranean Sea. Geomorphology 327:264-283

Mollard E, Martel C, Bourdier JL (2012) Decompression-induced crystallization in hydrated silica-rich melts: empirical models of experimental plagioclase nucleation and growth kinetics. J Pet 53:1743-1766

Mollo S, Giacomoni PP, Coltorti M, Ferlito C, Iezzi G, Scarlato P (2015) Reconstruction of magmatic variables governing recent Etnean eruptions: constraints from mineral chemistry and P-T$f \mathrm{O}_{2}-\mathrm{H}_{2} \mathrm{O}$ modelling. Lithos 212-215:311-320

Mollo S, Blundy JD, Giacomoni PP, Nazzari M, Scarlato P, Coltorti M, Langone A, Andronico D (2017) Clinopyroxene-melt element partitioning during interaction between trachybasaltic magma and siliceous crust: clues from quartzite enclaves at Mt. Etna Volcano Lithos 284-285:447-461

Monaco C, Tapponier P, Tortorici L, Gillot PY (1997) Late Quaternary slips rates on the Acireale-Piedimonte normal faults and tectonic origin of Mt. Etna (Sicily). Earth Planet Sci Lett 147:125-139

Monaco C, Catalano S, Cocina O, De Guidi G, Ferlito C, Gresta S, Musumeci C, Tortorici L (2005) Tectonic control on the eruptive dynamics at Mt. Etna Volcano (Sicily) during the 2001 and 2002-2003 eruptions. J Volcanol Geotherm Res 144:211-233

Morimoto N (1988) Nomenclature of pyroxenes. Miner Mag 52:535-550

Neri M (2010) Rapporto settimanale sull'attività eruttiva dell'Etna (10-16 Maggio). Report INGV of May 10-16, 2010. www.ct. ingv.it (in Italian)

Papale P (1999) Modeling of the solubility of a two-component $\mathrm{H}_{2} \mathrm{O}+\mathrm{CO}_{2}$ fluid in silicate liquids. Am Miner 84:477-492

Patanè $\mathrm{D}$, Barberi $\mathrm{G}$, Cocina $\mathrm{O}$, De Gori $\mathrm{P}$, Chiarabba $\mathrm{C}$ (2006) Timeresolved seismic tomography detects magma intrusions at Mount Etna. Science 313:821-825

Patanè D, Aiuppa A, Aloisi M, Behncke B, Cannata A, Coltelli M, Di Grazia G, Gambino S, Gurrieri S, Mattia M, Salerno G (2013) Insights into magma and fluid transfer at Mount Etna by a 
multi-parametric approach: a model of the events leading to the 2011 eruptive cycle. J Geophys Res 118:1-21

Peccerillo A, Lustrino M (2005) Compositional variation of Plio-Quaternary magmatism in the circum-Tyrrhenian area: deep versus shallow mantle processes. In: Foulger GR, Natland JH, Presnall DC, Anderson DL (eds) Plates, plumes, and paradigms. Geological Society of America Special Papers, vol 338:, pp 421-434

Putirka KD (2008) Thermometers and barometers for volcanic system. In: Putirka KD, Tepley F (eds) Minerals, inclusions, and volcanic processes. Reviews in mineralogy and geochemistry, vol 69, pp $61-120$

Putirka K, Ryerson FJ, Mikaelian H (2003) New igneous thermobarometers for mafic and evolved lava compositions, based on clinopyroxene+liquid equilibria. Am Miner 88:1542-1554

Putirka K, Perfit M, Ryerson FJ, Jackson MG (2007) Ambient and excess mantle temperatures, olivine thermometry, and active vs. passive upwelling. Chem Geol 241:177-206

Riker JM, Blundy JD, Rust AC, Botcharnikov RE, Humphreys MCS (2015) Experimental phase equilibria of a Mount St. Helens rhyodacite: a framework for interpreting crystallization paths in degassing silicic magmas. Contrib Miner Pet 170:1-22

Rittmann A (1965) Notizie sull'Etna. Supplemento al Nuovo Cimento 3(I): 1117-1123

Roeder PL, Emslie RF (1970) Olivine-liquid equilibrium. Contrib Miner Pet 29:275-289
Tanguy JC, Condomines M, Kieffer G (1997) Evolution of Mount Etna magma: constraints on the present feeding system and eruptive mechanism. J Volcanol Geotherm Res 75:221-250

Tsuchiyama A (1985) Dissolution kinetics of plagioclase in the melt of the system diopside- albite-anorthite, and the origin of dusty plagioclase in andesites. Contrib Miner Pet 89:1-16

Viccaro M, Ferlito C, Cortesogno L, Cristofolini R, Gaggero L (2006) Magma mixing during the 2001 event at Mt. Etna (Italy): effects on the eruptive dynamics. J Volcanol Geotherm Res 149:139-159

Viccaro M, Giacomoni PP, Ferlito C, Cristofolini R (2010) Dynamics of magma supply at Mt. Etna volcano (Southern Italy) as revealed by textural and compositional features of plagioclase phenocrysts. Lithos 116:77-91

Waters LE, Lange RA (2015) An updated calibration of the plagioclase-liquid hygrometer-thermometer applicable to basalts through rhyolites. Am Miner 100:2172-2185

Publisher's Note Springer Nature remains neutral with regard to jurisdictional claims in published maps and institutional affiliations. 